\title{
Metals in bivalve mollusks from the Jaco Scar seep, Pacific, Costa Rica
}

\author{
José A. Vargas ${ }^{1}$, David R. Hilton ${ }^{2 \dagger}$, Carlos Ramírez ${ }^{3}, \&$ Johan Molina ${ }^{4}$ \\ 1. Centro de Investigación en Ciencias del Mar y Limnología (CIMAR), Universidad de Costa Rica, 11501-2060, San \\ José, Costa Rica; jose.vargas@.ucr.ac.cr \\ 2. Scripps Institution of Oceanography, Geosciences Research Division, University of California, San Diego, California, \\ 92093-0244, U.S.A. Deceased January 2018. \\ 3. Escuela Centroamericana de Geología, Universidad de Costa Rica. 11501-2060, San José, Costa Rica. \\ 4. Centro de Investigación en Contaminación Ambiental (CICA), Universidad de Costa Rica, 11501-2060, San José, \\ Costa Rica; johan.molina@.ucr.ac.cr
}

Received 21-III-2017. Corrected 07-VI-2017. Accepted 03-I-2018.

\begin{abstract}
Deep sea-research has made significant discoveries thanks to the availability of high resolution bathymetric mapping and vehicles able to reach hydrothermal vents and cold seeps. The Pacific continental margin of Costa Rica includes cold seeps that are inhabited by vesicomyid clams, which are expected to accumulate metals. Data on metals from cold seep clams are scarce. Thus, the objective of this study is to present the concentrations of $\mathrm{Al}, \mathrm{Cd}, \mathrm{Cu}, \mathrm{Fe}, \mathrm{Pb}, \mathrm{Mn}, \mathrm{Ni}, \mathrm{Sb}$ and $\mathrm{Zn}$ in samples from seven clams, a mussel, sediment, and a rock, together with clam morphometric data. The bivalves (Archivesica sp.?) were collected in 2005 at a depth of $1888 \mathrm{~m}$ on the Jaco Scar (0906' N - 84 50' W) during DSRV Alvin dive 4129 . Metals were analyzed by Flame Atomic Absorption Spectrometry (FAAS) and Graphite Furnace (GFAAS). Concentrations are in $\mu \mathrm{g} / \mathrm{g}$ dry weight. The order of decreasing maximm concentrations and range in tissues of seven clams, were: $\mathrm{Zn}$ $(43.4-266.3)>\mathrm{Fe}(27.2-100.0)>\mathrm{Al}(5.0$ - 69.9) $>\mathrm{Cd}(0.1-12.2)>\mathrm{Sn}(2.8-9.5)>\mathrm{Cu}(4.0-7.3)>\mathrm{Mn}(1.1$ - 2.2) $>\mathrm{Pb}(0.2-0.8)>\mathrm{Ni}(0.19-0.58)$. The gills had the maximum concentrations of Fe and Al. Maximum concentrations in the only mussel specimen collected, were: $\mathrm{Zn}(80.4$ - gills), Fe (70.6 - gills), $\mathrm{Cu}$ (31.0 - gills), $\mathrm{Al}$ (26.6 - gills), Sn (4.8 - mantle), Mn (1.7 - mantle), Ni (0.97 - muscle), Pb (0.7 - muscle), Cd (0.57 - gills). The sediment sample had: Al (40 800), Fe (26 500), Mn (72.0), Zn (64.7), Cu (29.4), Ni (19.3), Sn (15.5), Pb (2.98), Cd (0.16). A rock fragment had: Fe (15 650), Al (9 240), Mn (170), Sn (99.5), Zn (36.5), Ni (20.4), Cu (13.4), $\mathrm{Pb}$ (1.6), Cd (traces). Clam gills concentrated metals such as Fe and Al. Fe was below the range reported for hydrothermal vent clams, while concentrations of other metals were near the lower range. $\mathrm{Fe}, \mathrm{Cd}, \mathrm{Mn}$, and $\mathrm{Pb}$ in mussel tissues were lower than those in mussels from hydrothermal vent sites, while $\mathrm{Cu}$ and $\mathrm{Zn}$ were within the range. Metals in the sediment and rock samples appeared very rich in certain metals like $\mathrm{Al}$ and $\mathrm{Fe}$ and very poor in others, such as Cd. There is a paucity of information on metals and pollutants in clams and other macrofaunal species from Costa Rican cold seeps. Data presented herein must be complemented with future studies conducted jointly on the geochemistry, biology, and management of these deep-sea systems. Rev. Biol. Trop. 66(Suppl. 1): S269-S279. Epub 2018 April 01.
\end{abstract}

Key words: deep sea, methane seeps, Vesicomyidae, Plioclardiinae, Archivesica, tectonics, subduction.

In 1979 the Marine and Limnology Research Center (CIMAR) was established at the University of Costa Rica. Since then more than 1000 scientific papers have been published by local and visiting scientists, a milestone that is the main motivation for this special issue of the Revista de Biología Tropical. The study of intertidal and shallow water ecosystems of both Pacific and Caribbean coasts was and continues to be a priority.

Most of the early CIMAR research on the Pacific coast focused on the Gulf of Nicoya estuary, an important fishing ground and the site of the main Pacific port facilities of Costa Rica. Nearly 100 papers on the biology, physics and chemistry of the waters and sediments 
of the estuary were released during the 1980s, mainly as part of an international collaborative effort that allowed the $15 \mathrm{~m}$ long $R V$ Skimmer (University of Delaware, USA) to operate in the Gulf (Vargas, 1995). The diversity of epibenthic and infaunal invertebrates from the Gulf was evaluated by sampling with grab, and trawl, respectively, to a depth of $65 \mathrm{~m}$. (Maurer \& Vargas, 1984; Maurer et al., 1984). The first report on trace metals in invertebrates and sediments from the Gulf was published by Dean, Maurer, Vargas, \& Tinsman (1986). The study of tidal flats in the Gulf of Nicoya followed as a key area of research (Vargas, 1996; Ditmann \& Vargas, 2001).

In the 1990's international cooperation made possible joint cruises aboard the $50 \mathrm{~m}$ long $R V$ Victor Hensen (Zentrum fur Marine Tropenokologie, Bremen, Germany), which allowed deeper sampling in other Pacific coastal embayments. Box corer and trawl nets were used to study the fauna and biogeochemistry of sediments to depths of $200 \mathrm{~m}$ in the Gulf of Nicoya, the Golfo Dulce anoxic basin, and Coronado Bay (Wolff, Chavarría, Koch, \& Vargas, 1998; Dalsgaard, Canfield, Peterson, Thamdrup, \& Acuña-González, 2003).

More recently, collaboration with private deep-sea shrimp trawling vessels has facilitated the study of benthic fauna at depths near $350 \mathrm{~m}$ along the Pacific coast of Costa Rica (Wehrtmann, Herrera-Correal, Vargas, \& Hernáez, 2010). Another cooperative effort allowed access to the Deep See submersible (Undersea Hunter Group) to study the deep water $(450 \mathrm{~m})$ at the Isla del Coco National Park, a Pacific site located 300 nautical miles from the Gulf of Nicoya (Cortés \& Blum, 2008; Starr, Cortés, Barnes, Green, \& Breedy, 2012).

Joint biological research in waters deeper than $400 \mathrm{~m}$ has been sporadic. Deep water surveys on the Pacific coast of Costa Rica have emphasized the geochemisty and biology of cold seeps and similar environments, particularly the Jaco Scar, South of the Gulf of Nicoya, and Mounds 11 and 12 West of
Coronado Bay (Levin et al., 2012). According to Levin (2005) cold seeps occur in the sea floor where reduced sulphur and methane reach the surface without an important rise in water temperature. The macrofauna of cold seeps of Costa Rica includes tubeworms, clams, mussels, and microbial mats (Suess, 2014).

Several new species of deep sea invertebrates have been described by visiting scientists based on material collected in Costa Rica, including deep sea clams such as those found by Barry \& Kochevar (1999) and Martin \& Gofredi (2012). The finding in 2009 at a depth of $1000 \mathrm{~m}$ on Mound 12 and follow up description by visiting and local scientists of a new species of antiphatatian coral (Opresko \& Breedy, 2010) is a notable exception.

In 2005 a geochemistry cruise aboard the $R V$ Atlantis (AT-11) using the Deep Sea Research Vessel (DSRV) Alvin (Dive 4129) focused on the Jaco Scar (Furi et al., 2010). According to Mau, Rehder, Sahling, Schleicher, \& Linke (2012), the Jaco Scar, which extends from $1000 \mathrm{~m}$ to $2400 \mathrm{~m}$ deep, is a slide of the ocean floor caused by seamount subduction. There methane rich fluids lead to the hydrogen sulfide used by most vent fauna as an energy source.

Samples of coastal bivalve mollusks from the Gulf of Nicoya were being analyzed at the time for metal concentrations (Vargas, AcuñaGonzález, Gómez, \& Molina, 2015) Most of the reports on trace metals in deep sea clams come from specimens collected at hydrothermal vents, where strong water temperature gradients are typical. Thus, the access to samples of bivalves from the Jaco Scar cold seep was kindly allowed upon request by the senior author. Tissue samples from these mollusks were included in the metal analysis and the results reported herein.

The objective of this study is to report data on trace metals in tissues of vesicomyid clams, and in a mussel, sediment, and rock samples from the Jaco Scar, and to provide morphometric data of the clam shells. 


\section{MATERIALS AND METHODS}

Mollusks were collected on June $13^{\text {th }}$, 2005 during dive 4129 of the DSRV Alvin operated from RV Atlantis (Cruise AT-11) at Jaco Scar (09-06.836 N - 84-50.408 W) at a depth of $1888 \mathrm{~m}$. The site is located south of the mouth of the Gulf of Nicoya estuary and is inhabited by chemosynthetic communities that include bacterial mats, vesicomyid clams, mussels, tube worms, and other invertebrates (Furi et al., 2010).

After collection, the bivalves were frozen on board the ship and later transported to the CIMAR laboratory in a plastic cooler. The collection included one specimen of deep-sea mussel and 13 specimens of vesicomyid clams (Numbered 01 to 13) of which five were preserved whole (shells and tissues) in $90 \%$ ethyl alcohol. A rock fragment was also collected. A small clam (\# 08) was found dead at the time of collection and had the space between valves filled with soft dark gray sediment. Seven clams were open and soft parts removed with a plastic knife and stored frozen $\left(-18^{\circ} \mathrm{C}\right)$ until analyses. A valve (usually the right one) of each of the seven clams was weighed (grams) for reference. The 13 clams were measured to the nearest $\mathrm{mm}$ for length $(\mathrm{L})$, height $(\mathrm{H})$, and width (W, both valves attached, when intact) and ratios $(\mathrm{H} / \mathrm{L}, \mathrm{W} / \mathrm{L}, \mathrm{W} / \mathrm{H})$ computed. Distance from the umbo to the anterior region was also measured. Empty shells and whole specimens were deposited in the mollusk collection of the Museum of Zoology, University of Costa Rica (MZUCR).

Nine metals (Aluminum, Cadmium, Copper, Iron, Lead, Manganese, Nickel, Tin and Zinc) were selected for analysis. All metal determinations were performed as described in Vargas et al. (2015): Tissue samples were weighed after drying in an oven at $65{ }^{\circ} \mathrm{C}$ for $48 \mathrm{~h}$. The rock fragment from the site, as well as the sediment trapped in clam $\# 08$, were included in the metal analysis. Dried samples were ground to powder and sub-samples of $1.00 \mathrm{~g}$ to $4.00 \mathrm{~g}$ placed in Teflon containers with $6 \mathrm{~mL}$ of high purity nitric acid, $2 \mathrm{~mL}$ of high purity hydrochloric acid, and pressure-digested in a microwave oven $\left(C E M^{\circledR} M A R S x\right)$. After digestion, the containers were left to reach room temperature, the liquid was transferred to $100 \mathrm{~mL}$ volumetric flasks, and diluted with deionized water. Certified reference materials and blank tests were also run. $\mathrm{Cu}, \mathrm{Fe}, \mathrm{Mn}$ and Zn were analyzed by Flame Atomic Absorption Spectrometry (Perkin Elmer ${ }^{\circledR}$ 3300) and Al, $\mathrm{Cd}, \mathrm{Ni}, \mathrm{Pb}$ and $\mathrm{Sn}$ by Graphite Furnace Atomic Absorption Spectrometry (Perkin Elmer ${ }^{\circledR}$ HGA $600)$. Calibration curves were produced against certified standards for each element according to the UCR-CICA accredited protocols. Concentrations were determined in triplicate. The results are expressed in $\mu \mathrm{g} / \mathrm{g}$ dry weight (dw). Detection limits typical values $(\mu \mathrm{g} / \mathrm{g})$ were: 18 for $\mathrm{Zn}, 1.9$ for $\mathrm{Fe}, 0.40$ for $\mathrm{Al}, 0.10$ for $\mathrm{Sn}$, 0.027 for $\mathrm{Pb}, 0.022$ for $\mathrm{Ni}$, and 0.0020 for $\mathrm{Cd}$. Detection limitis for $\mathrm{Cu}$ and $\mathrm{Mn}$ were $6.7 \mathrm{ug} / \mathrm{g}$ and $2.2 \mathrm{ug} / \mathrm{g}$, respectively.

\section{RESULTS}

A total of 13 vesicomyid clams and one mussel were collected (Table 1, Figs. 1 and 2). External and internal views of the valves of one of the larger clams (\#04) collected are included in Fig. $1 \mathrm{~A}, \mathrm{~B}$, respectively. A hand drawing of the external and internal view of another clam (\#07) is illustrated in Fig. 1 D, E. Details of hinges of clams 04 and 07 are included in Fig. 1C, F, G, respectively. Recently collected clams had a sulfur odor and tissues and shells were smeared with a red pigment (Fig. 1H, I). Photographs of the 13 clams are included in Fig. 2, as and aid for future identification of the species name. The surface of the clams had a chalky appearance and a deshicent olive brown periostracum was present mostly near the edges (Fig. 2). Morphometric data as well as the ratios of $\mathrm{H} / \mathrm{L}, \mathrm{W} / \mathrm{L}$, and $\mathrm{W} / \mathrm{H}$ are listed in Table 1. The shortest and longest valves measured $87 \mathrm{~mm}$ and $200 \mathrm{~mm}$, respectively. $\mathrm{H} / \mathrm{L}$ valve ratios ranged from 0.37 to 0.43 . The right valve of the longest shell weighed 76 grams and had a thickness of about $2 \mathrm{~mm}$ at its center (Table 1). The catalogue codes for 
TABLE 1

Morphometric data in mm (Length, Heigth, Width, ratios $\mathrm{H} / \mathrm{L}, \mathrm{W} / \mathrm{L}, \mathrm{W} / \mathrm{H}$ ) and length Umbo to Anterior margin ( $\mathrm{U}$ to $\mathrm{AM}$ ) of the vesicomyid clams. Jaco Scar, Pacific coast of Cosfa Rica ( $\left.9^{\circ} 06^{\prime} \mathrm{N}-84^{\circ} 50^{\prime} \mathrm{W}\right)$. DSRV Alvin dive 4129, June $13^{\text {th }}, 2005$

\begin{tabular}{|c|c|c|c|c|c|c|c|c|}
\hline Specimen & Length & Height & Width & $\mathrm{H} / \mathrm{L}$ & $\mathrm{W} / \mathrm{L}$ & $\mathrm{W} / \mathrm{H}$ & $\mathrm{U}$ to $\mathrm{AM}$ & Weight $(\mathrm{g})$ \\
\hline \multicolumn{9}{|l|}{ Shells } \\
\hline MZUCR10425-01 & 160 & 64 & 44 & 0.40 & 0.28 & 0.68 & 47 & 44 \\
\hline MZUCR10425-02 & 150 & 59 & 46 & 0.39 & 0.31 & 0.78 & 38 & 33 \\
\hline MZUCR10425-03 & 162 & 62 & $* *$ & 0.38 & $* *$ & $* *$ & 40 & 51 \\
\hline MZUCR10425-04 & 188 & 71 & 59 & 0.38 & 0.31 & 0.83 & 48 & 58 \\
\hline MZUCR10425-05 & 175 & 68 & 55 & 0.39 & 0.31 & 0.83 & 45 & 56 \\
\hline MZUCR10425-06 & 200 & 80 & $* *$ & 0.40 & $* *$ & $* *$ & 50 & 76 \\
\hline MZUCR10425-07 & 163 & 67 & 60 & 0.41 & 0.37 & 0.89 & 45 & 54 \\
\hline MZUCR10425-08 & 87 & 38 & 31 & 0.43 & 0.39 & 0.81 & 37 & 7 \\
\hline \multicolumn{9}{|l|}{ Whole } \\
\hline MZUCR10425-09 & 170 & 63 & 49 & 0.37 & 0.29 & 0.78 & 35 & \\
\hline MZUCR10425-10 & 160 & 64 & 51 & 0.40 & 0.32 & 0.79 & 35 & \\
\hline MZUCR10425-11 & 170 & 69 & 58 & 0.40 & 0.34 & 0.84 & 43 & \\
\hline MZUCR10425-12 & 133 & 57 & 47 & 0.43 & 0.35 & 0.82 & 34 & \\
\hline MZUCR10425-13 & 175 & 67 & 63 & 0.38 & 0.36 & 0.94 & 40 & \\
\hline
\end{tabular}

the malacology collection of the Museum of Zoology, University of Costa Rica (MZUCR) for each of the eight shells and five whole specimens of clams are also listed in Table 1. The only mussel collected had a length of 130 mm (Fig. 1J), and had a thin and brittle shell.

Concentrations of nine metals (Aluminum, Cadmium, Copper, Iron, Lead, Manganese, Nickel, Tin and Zinc) in tissue samples from seven clams, the mussel, sediment, and the rock from the site are inclued in Table 2. The concentrations $(\mu \mathrm{g} / \mathrm{g})$, in decreasing order and range, in clam tissues were: $\mathrm{Zn}(43.3$ - 266.3) > $\mathrm{Fe}(27.2-100.0)>\mathrm{Al}(5.08-69.9)>\mathrm{Cd}(0.11$ - 12.23) > Sn $(2.85-9.50)>\mathrm{Cu}(4.0-7.3)>$ $\mathrm{Mn}(1.1-2.2)>\mathrm{Pb}(0.24-0.79)>\mathrm{Ni}(0.188$ - 0.582). The gills had the maximum concentrations of $\mathrm{Fe}$ and $\mathrm{Al}$. Higher concentrations of $\mathrm{Pb}, \mathrm{Zn}$ and $\mathrm{Sn}$ were found in muscle tissues, while $\mathrm{Cd}, \mathrm{Cu}, \mathrm{Mn}$ an $\mathrm{Ni}$ were found in higher concentrations in foot tissues.

Maximum concentrations $(\mu \mathrm{g} / \mathrm{g})$ of metals in tissues of the only specimen of mussel collected, were: Zn (80.4 - gills), Fe (70.6 - gills), $\mathrm{Al}$ (26.6 - gills), Sn (4.87 - mantle), Cu (31.0
- gills), Mn (1.7 - mantle), Ni (0.97 - muscle), $\mathrm{Pb}$ (0.699 - muscle), Cd (0.575 - gills). Concentrations $(\mu \mathrm{g} / \mathrm{g})$ of metals in the sediment trapped in shell \#10, were: Al (40 800), Fe (26 500), Mn (72.0), Zn (64.7), Cu (29.4), Ni (19.3), Sn (15.56), Pb (2.98), Cd (0.16). Metals $(\mu \mathrm{g} / \mathrm{g})$ in the rock fragment were: Fe (15 650), Al (9 240), Mn (169.9), Sn (99.5), Zn (36.5), $\mathrm{Ni}$ (20.4), Cu (13.4), Pb (1.63), Cd (traces).

A comparison of metal concentrations $(\mu \mathrm{g} / \mathrm{g})$ found in this study, with four reports from the literature is included in Table 3, together with data on metals in the razor clam Tagelus affinis from a sand flat in the Gulf of Nicoya.

\section{DISCUSSION}

Hydrothermal vents and cold seeps are deep-sea environments discovered during the last decades of the twentieth century, thanks in part to the development of human-occupied vehicles (HOVs), remotedly operated vehicles (ROVs) and high-resolution sea floor mapping. Seeps are benthic systems supported by both 

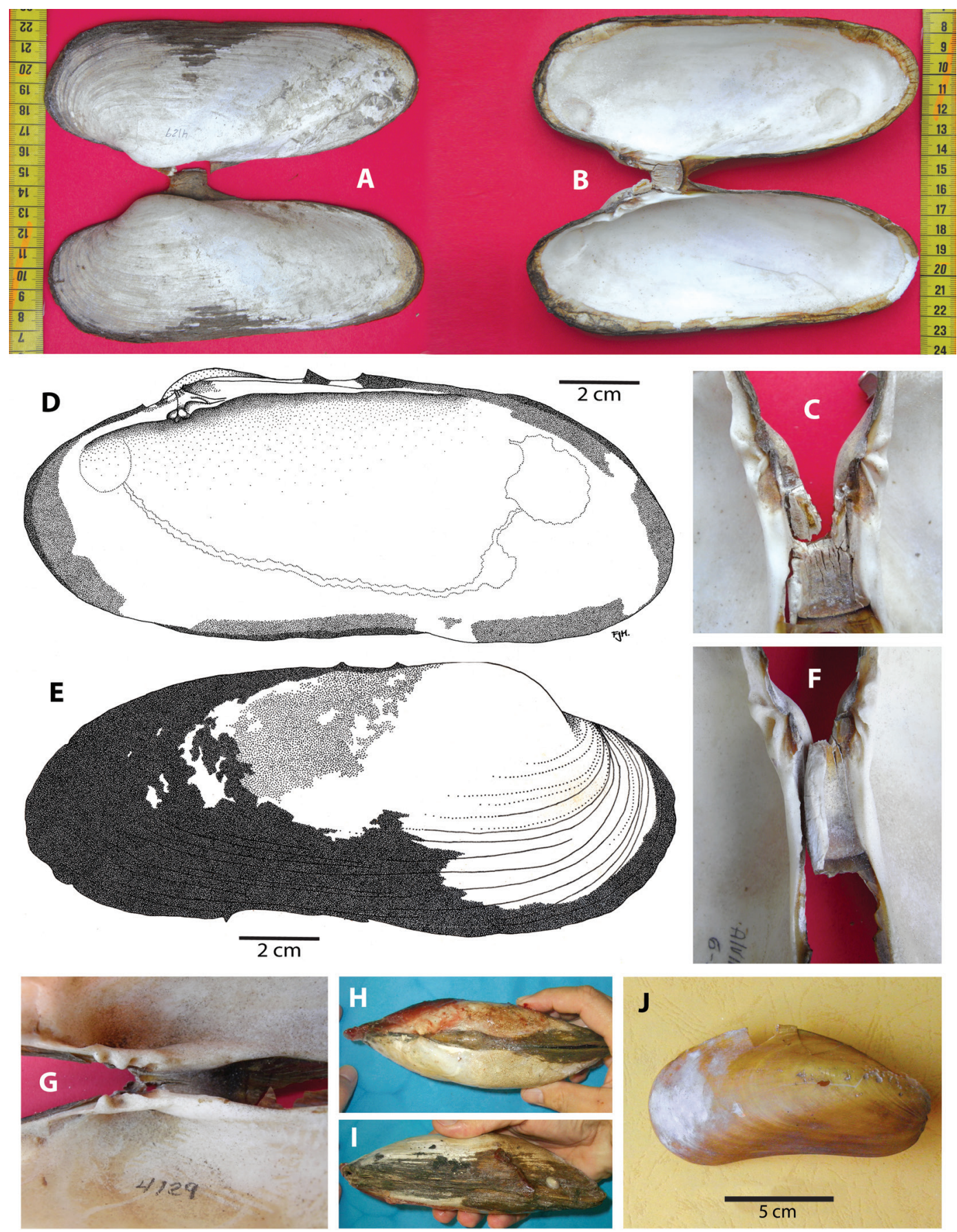

Fig. 1. A. B. External and internal view of valves of specimen 04. Scale bar in $\mathrm{cm}$. C. Detail of the hinge region of clam 04. D. E. Internal and external drawing of right valve of shell 07 , with scars of adductor muscles and pallial line. F. Detail of the hinge region of shell 07. G. Detail of hinge of shell 01. H. I. Dorsal and ventral view of whole specimen with hemoglobine stained shell, and epizoic limpet. J. Mussel shell. Jaco Scar, $1888 \mathrm{~m}$, Pacific coast of Costa Rica (09 $\left.06^{\circ} \mathrm{N}-84^{\circ} 50^{\prime} \mathrm{W}\right)$. DSRV Alvin, dive 4129. June $13^{\text {th }}, 2005$. 

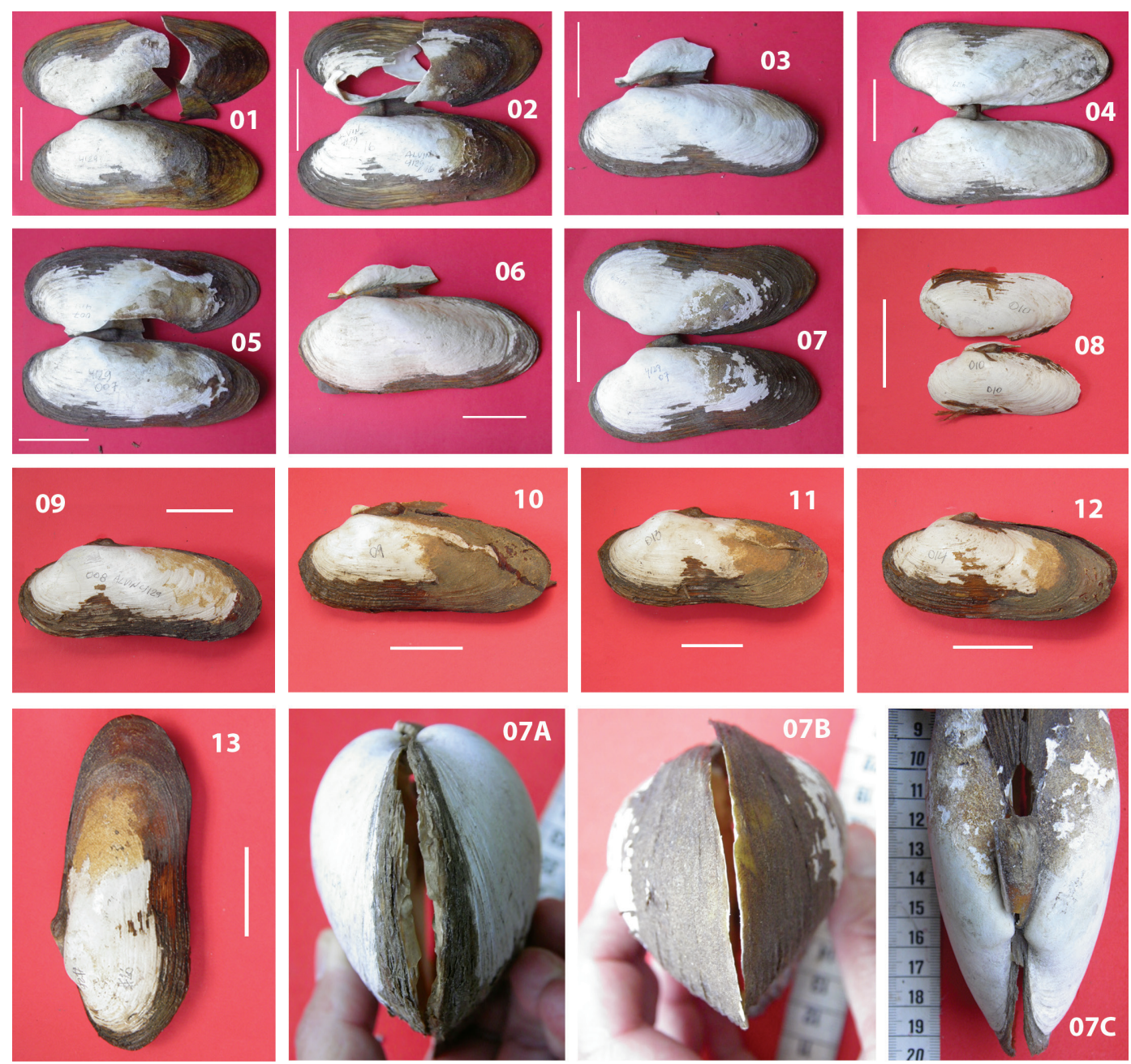

Fig. 2. A. (1-13). Photographs of the clams: 1-8 (shells only), 9-13 (Shells with soft tissues). 07 A, B, C: Anterior, posterior

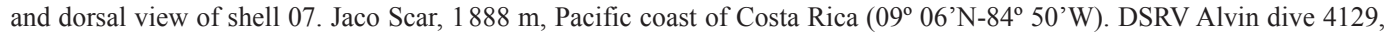
June $13^{\text {th }}, 2005$. Scale bars $(1-13)=5 \mathrm{~cm}$.

soft sediments and carbonate rocks. Clams of the family Vesicomyidae usually form large clusters in the sediments and mudstones of these sites (Levin et al., 2015). Originally considerd as different systems, recent evidence points to the existence of intermediate hydrothermal-seep environments along a continuum (Levin et al., 2012).

Aggregations of deep sea clams generally include more than one species at a site, the species composition varying with environmental conditions, and the presence of cryptic species complexes is expected (Watanabe et al.,
2013). Plasticity in shell morphologies is also a problem for the identification of species. The subfamily Plioclardiinae includes relatively large clams living in a depth range of 100 to $6809 \mathrm{~m}$. The majority of the nearly 110 species are associated to cold water hydrocarbon seeps (Johnson, Krylova, Audzijonyte, Sahling \& Vrijenhoek, 2017).

On the Pacific coast of Costa Rica, the seep sites known as Mound 11, Mound 12 and Jaco Scar are characterized by chemosynthethic macrofauna (clams, mussels, tube worms), authigenic carbonate rocks, and fine sediments 
TABLE 2

Concentrations ( $\mu \mathrm{g} / \mathrm{g}$ ) of metals ( $\mathrm{Fe}, \mathrm{Cd}, \mathrm{Pb}, \mathrm{Zn}, \mathrm{Cu}, \mathrm{Mn}, \mathrm{Ni}, \mathrm{Sn}, \mathrm{Al})$ in tisúes (foot, muscle, gill, mantle), and mean $(\mathrm{n}=3)$ determined by FAAS and GFAAS in specimens of clams (Vesicomyidae), a mussel, sediment and rock from

1888 m depth, Jaco Scar, Pacific coast of Costa Rica (9º $06^{\prime}$ N $-84^{\circ} 50^{\prime}$ W). DSRV Alvin dive 4129, June $13^{\text {th }}, 2005$

\begin{tabular}{lccccccccc} 
Tissue & Fe & $\mathbf{C d}$ & $\mathbf{P b}$ & $\mathbf{Z n}$ & $\mathbf{C u}$ & $\mathbf{M n *}$ & $\mathbf{N i}$ & $\mathbf{S n}$ & $\mathbf{A l}$ \\
Clams & & & & & & & & & \\
Foot 01 & $68.4+4.1$ & $12.23 \pm 0.85$ & $0.43 \pm 0.14$ & $264.3 \pm 4.4$ & $<3.7$ & $<1.1$ & $0.331 \pm 0.079$ & $6.83 \pm 0.12$ & $13.81 \pm 0.34$ \\
Foot 03 & $27.2 \pm 4.4$ & $0.286 \pm 0.025$ & $0.24 \pm 0.17$ & $72.56 \pm 0.93$ & $<4.2$ & $<1.3$ & $<0.22$ & $5.26 \pm 0.18$ & $19.33 \pm 0.47$ \\
Foot 05 & $80.3 \pm 3.5$ & $0.612 \pm 0.055$ & $0.751 \pm 0.065$ & $261.3 \pm 9.3$ & $<7.3$ & $<2.2$ & $0.582 \pm 0.066$ & $2.85 \pm 0.19$ & $24.60 \pm 1.50$ \\
Foot 07 & $57.2 \pm 2.0$ & $0.165 \pm 0.019$ & $0.722 \pm 0.037$ & $166.5 \pm 5.3$ & $<4.0$ & $<1.2$ & $0.396 \pm 0.036$ & $3.54+0.16$ & $13.50 \pm 1.50$ \\
Muscle 02 & $41.6 \pm 4.4$ & $0.330 \pm 0.043$ & $0.35 \pm 0.16$ & $74.19 \pm 0.91$ & $<4.1$ & $<1.3$ & $0.188 \pm 0.092$ & $5.87 \pm 0.18$ & $10.53 \pm 0.25$ \\
Muscle 04 & $38.8 \pm 3.7$ & $0.399 \pm 0.029$ & $0.51 \pm 0.13$ & $43.37 \pm 0.48$ & $<3.5$ & $<1.1$ & $0.512 \pm 0.074$ & $9.50 \pm 0.18$ & $5.08 \pm 0.12$ \\
Muscle 05 & $81.8 \pm 2.9$ & $0.192 \pm 0.027$ & $0.787 \pm 0.053$ & $266.3 \pm 8.1$ & $<6.0$ & $<1.8$ & $0.569 \pm 0.054$ & $6.44 \pm 0.28$ & $10.91 \pm 0.91$ \\
Muscle 06 & $55.5 \pm 2.9$ & $0.110 \pm 0.026$ & $0.544 \pm 0.053$ & $88.4 \pm 2.2$ & $<6.0$ & $<1.8$ & $0.311 \pm 0.057$ & $3.14 \pm 0.17$ & $7.64 \pm 0.63$ \\
Gills 03 & $100.0 \pm 3.3$ & $0.131 \pm 0.029$ & $0.375 \pm 0.061$ & $117.4 \pm 4.1$ & $<6.7$ & $<2.0$ & $0.274 \pm 0.064$ & $2.94 \pm 0.18$ & $69.90 \pm 4.50$ \\
Mantle 04 & $76.9 \pm 2.9$ & $0.526 \pm 0.047$ & $0.523 \pm 0.054$ & $72.9 \pm 2.0$ & $<6.1$ & $<1.8$ & $0.402 \pm 0.056$ & $4.17 \pm 0.20$ & $25.7 \pm 1.50$ \\
Mussel & & & & & & & & & \\
Muscle & $29.8 \pm 2.5$ & $0.456 \pm 0.041$ & $0.699 \pm 0.046$ & $34.65 \pm 0.75$ & $<5.2$ & $<1.6$ & $0.972 \pm 0.050$ & $4.62 \pm 0.21$ & $11.63 \pm 0.98$ \\
Mantle & $20.6 \pm 2.9$ & $0.132 \pm 0.026$ & $0.516 \pm 0.052$ & $29.44 \pm 0.74$ & $<5.8$ & $<1.7$ & $0.778 \pm 0.053$ & $4.87 \pm 0.22$ & $9.30 \pm 0.89$ \\
Gills & $70.6 \pm 2.1$ & $0.575 \pm 0.050$ & $0.512 \pm 0.035$ & $80.4 \pm 2.4$ & $31.0 \pm 2.2$ & $<1.2$ & $0.346 \pm 0.035$ & $3.05 \pm 0.14$ & $26.60 \pm 1.70$ \\
Sediment & $26500 \pm 1200$ & $0.158 \pm 0.014$ & $2.98 \pm 0.18$ & $64.7 \pm 1.6$ & $29.4 \pm 2.0$ & $72.0 \pm 2.2$ & $19.3 \pm 1.1$ & $15.56 \pm 0.67$ & $40800 \pm 3000$ \\
Rock & $15650 \pm 490$ & $<0.0023$ & $1.63 \pm 0.15$ & $36.48 \pm 0.42$ & $13.38 \pm 0.75$ & $169.9 \pm 5.4$ & $20.41 \pm 0.48$ & $99.5 \pm 2.5$ & $9240 \pm 210$ \\
\hline
\end{tabular}

The uncertainty $( \pm$ ) corresponds to the expanded uncertainty using a coverage factor $\mathrm{k}=2$.

* Detection limits vary between samples since LD depends upon linear regression for each metal, the complexity of the matrix as well as the sample amount digested.

TABLE 3

Concentrations (ug/g) of metals (Fe, Cd, $\mathrm{Pb}, \mathrm{Zn}, \mathrm{Cu}, \mathrm{Mn}, \mathrm{Ni}, \mathrm{Sn}, \mathrm{Al}$ ) in tissues of: deep sea clams reported in three previous studies (A,B,C), and in this study (D). Metals (ug/g) in: the mussel, Bathymodiolus (E), the Jaco Scar mussel (F), the intertidal razor clam, Tagelus affinis $(\mathbf{G})$

\begin{tabular}{|c|c|c|c|c|c|c|c|c|c|}
\hline Tissue & $\mathrm{Fe}$ & Cd & $\mathbf{P b}$ & Zn & $\mathrm{Cu}$ & Mn & $\mathbf{N i}$ & Sn & Al \\
\hline \multicolumn{10}{|l|}{ Clams } \\
\hline A & $760 \pm 240$ & $9.8 \pm 0.8$ & $6.0 \pm 2.4$ & $2152 \pm 495$ & $148 \pm 10$ & $5 \pm 2$ & $<2.5$ & $<10.0$ & $<150$ \\
\hline B. Mantle & $277.5 \pm 27$ & $12.3 \pm 5.5$ & $3.67 \pm 1.8$ & $419.1 \pm 79$ & $29.7 \pm 11.1$ & $10.6 \pm 1$ & ND & ND & ND \\
\hline B. Gills & $403.2 \pm 242$ & $115.2 \pm 196$ & $2.89 \pm 2.5$ & $844.8 \pm 1042$ & $8.26 \pm 5.8$ & $18 \pm 17$ & ND & ND & ND \\
\hline $\mathrm{C}$ & 125 to 452 & 1.12 to 4.32 & 1.42 to 4.1 & 120 to 3110 & 9.2 to 45.5 & 8.6 to 11.5 & ND & ND & ND \\
\hline D & 27.2 to 100.0 & 0.13 to 12.23 & 0.24 to 0.79 & 43.3 to 266.3 & 4.0 to 7.3 & 1.1 to 2.2 & 0.19 to 0.58 & 2.85 to 9.50 & 5.08 to 69.9 \\
\hline \multicolumn{10}{|l|}{ Mussel } \\
\hline E & 196 to 1495 & 1.3 to 11.1 & 1.2 to 29.7 & 65 to 187 & 23 to 352 & 3.2 to 15.2 & ND & ND & ND \\
\hline F & 20.6 to 70.6 & 0.132 to 0.575 & 0.512 to 0.699 & 29.44 to 80.4 & 5.2 to 31 & 1.2 to 1.6 & 0.346 to 0.972 & 3.05 to 4.87 & 9.3 to 26.6 \\
\hline G. T. affinis & 2160 & 0.69 & 1.37 & 206.7 & 21.6 & 255.2 & 4.13 & 3.74 & ND \\
\hline
\end{tabular}

ND = No data. A. Roesijadi \& Crecelius, (1984). B. Ruelas-Inzunza, Soto \& Paez-Osuna, (2003). C. Demina, Galkin, \& Shumilin, (2009). D. This study, clams, data from Table 2. E. Koshinsky, Kaush, \& Borowski, (2014). F. This study, mussel, data from Table 2. G. Vargas, Acuña-González, Gómez, \& Molina, (2015), maximum concentrations. 
(Furi et al., 2010). The Jaco Scar is an example of a site that has organisms with affinities to both vents and seeps. Its biodiversity appears relatively higher in comparison with other vents and seeps, since the presence of many yet undescribed species of mollusks is noteworthy (Levin et al., 2012).

The number on published papers on deepsea environments from the Pacific coast of Costa Rica is on the rise. Most of these studies have collected vesycomyid clams and the specimens have been assigned to different species names:

Vesicomyid clams, found partially buried in sediments at cold seeps sites located between 2900-3 800 m near the Jaco Scar, were described as $C$. diagonalis by Barry \& Kochevar (1999). They provide shell measurements and ratios to separate $C$. diagonalis from six other vesicomyid clam species. Their paratype collected in Costa Rica measures $201 \mathrm{~mm}$ and has a $\mathrm{H} / \mathrm{L}$ ratio of 0.39 The largest clam found during Alvin dive 4129 is $200 \mathrm{~mm}$ long and has a $\mathrm{H} / \mathrm{L}$ ratio of 0.40 However, the $\mathrm{W} / \mathrm{L}$ ratio (0.26) of $C$. diagonalis Costa Rican paratype is less than those (mean $=0.30$ ) of clams from dive 4129. Clam \#08 from dive 4129 has a dentition similar to $C$. diagonalis.

The study by Peek, Gaut, Feldman, Barry, Kochevar, Lutz, \& Vrijenhoek (2000) is among the earlier reports on vesicomyids associated to cold seeps on the Pacific coast $\left(09^{\circ} \mathrm{N}-86^{\circ} \mathrm{W}\right)$ of Costa Rica. The clams, collected at depths of $3000 \mathrm{~m}$ in soft sediments, were designated as Ectenagena extenta, Calytogena pacifica, and as "large- bodied" unidentified.

The review by Krylova \& Sahling (2006) includes 12 genera of Vesicomyid clams of which only two (Phreagena and Pleurophopsis) were listed as having shell lenghts near $200 \mathrm{~mm}$. More recently Krylova \& Sahling (2010) indicates that an undescribed species of Archivesica and the genera Laubiericoncha and Phreagena are present off Costa Rica.

A study of water chemistry at the Jaco Scar and the use of ROV video footage of the benthic fauna by Mau et al. (2012) pointed out to the existence of dense patches of vesicomyid clams identified as Calyptogena spp.

Levin et al. (2012) studied the bottom fauna of the Jaco Scar ( $9^{\circ} 7.05^{\prime}$ N - 85 $50.39^{\prime}$ W) at depths from $1752 \mathrm{~m}$ to $1805 \mathrm{~m}$. They found that the macrofauna was characterized by clams identified as Archivesica gigas. The mussels included new taxa close to Bathymodiolus thermophilus.

In another survey of the Jaco Scar, the new versicomyid 'Pliocardia' krylovata, was described based on 15 specimens collected in 2009 at a depth of $740 \mathrm{~m}$ at the Jaco Scar summit an at near $1000 \mathrm{~m}$ depth at Mound 12 (Martin \& Gofredi, 2012). However, P. krylovata is relatively small and subovate in shape (length 31 to $59 \mathrm{~mm}, \mathrm{H} / \mathrm{L}$ ratio 0.70 to 0.90 ) when compared with the 13 specimens from dive 4129.

Coan \&Valentich-Scott (2012) focused on the bivalves of tropical West America and provide photographs of the right valves and dentition of 15 species of vesicomyid clams, including A. gigas, C. costarricana, C. diagonalis, C. magnifica, L. angulata, and Phreagena kilmeri. The photographs (p.528) by Coan \&Valentich-Scott (2012) that share most resemblance with those from dive 4129 correspond to P. kilmeri. However, the ratio $\mathrm{H} / \mathrm{L}$ for P. kilmeri listed by Barry \& Kochevar (1999) is 0.51 , which is higher than the maximum (0.43) measured in this study.

Audzijonyte, Krylova, Sahling, \& Vrijenhoek (2012) report the presence on the Costa Rican Pacific Accretionary Wedge of undescribed species of vesicomyid clams of which several were provisionally assigned to the genus Archivesica.

Based on the above mentioned reports and morphological data, the clams found during dive 4129 at the Jaco Scar probably belong to the genus Archivesica. Further taxonomic work is needed to confirm this possibility.

Metal concentrations in low temperature fluids, such as those present in cold seeps, are expected to be lower than those in high temperature hydrothermal vent fluids (Koshinsky, Kaush, \& Borowski, 2014) Several groups of 
the nearby benthic macrofauna bioaccumulate many metals (Demina, 2016) However, most of the data on trace metals in tisses of deep sea mollusks comes from specimens collected at hydrothermal vents.

The pioneer study by Roesijadi \& Crecelius (1984) on trace metals in vesicomyid clams provides data for $C$. magnifica from a hydrothermal vent on the East Pacific Rise $\left(21^{\circ} \mathrm{N}-109^{\circ} \mathrm{W}\right)$ at a depth of $2600 \mathrm{~m}$. Highest concentrations $(\mu \mathrm{g} / \mathrm{g})$ of $\mathrm{Fe}$ and $\mathrm{Cd}$ were found in the gills, while the kidneys concentrated $\mathrm{Pb}$, $\mathrm{Cu}$, and $\mathrm{Sn}$.

Ruelas-Inzunza, Soto, \& Páez-Osuna (2003) studied metals in the clam Vesicomya gigas from a hydrothermal vent in the Gulf of California $\left(27^{\circ} \mathrm{N}-111^{\circ} \mathrm{W}\right)$. They found in the gills higher concentrations of $\mathrm{Fe}, \mathrm{Cd}, \mathrm{Mn}$ and $\mathrm{Zn}$. Aluminum, Tin, and Nickel were not included. However, their order of decreasing concentrations $(\mathrm{Zn}>\mathrm{Fe}>\mathrm{Cd}>\mathrm{Cu}>\mathrm{Mn}>$ $\mathrm{Pb}$ ) is the same as that found in our study for those metals.

Demina, Galkin \& Shumilin (2009) studied the metals in one specimen of $A$. gigas from the same vent site in the Gulf of California. The decreasing order and range (Min / Max) of concentrations $(\mu \mathrm{g} / \mathrm{g})$ found, was: $\mathrm{Zn}(120 /$ 3110), Fe (125 / 452), Cu (9.2 / 45.5), Mn (8.6 / 11.5), $\mathrm{Cd}$ (1.12 / 4.32), and $\mathrm{Pb}(1.42$ / 4.1) Zinc concentration in the gills had the highest concentration and widest range of any metal.

In clams of the Jaco Scar collected during dive 4129 the highest concentration $(\mu \mathrm{g} / \mathrm{g})$ of $\mathrm{Fe}$ (100) and $\mathrm{Al}$ (69.9) were found in the gills. The fact that gills accumulate more metals than other tissues in deep sea clams is a well known fact (Childress \& Fisher, 1992).

In spite of the fact that most of the information on metals in clams come from hydrothermal vents rather than from seep sites, the following results from the Jaco Scar seep are noteworthy when compared with the above mentioned three reports: First, clam gills also appear to concentrate certain metals like $\mathrm{Fe}$ and Al. Second, concentrations of $\mathrm{Fe}$ were below the range reported for hydrothermal vents. Third, concentrations of other metals were generally near the lower range reported for hydrothermal vent sites.

Vesicomyid clams from vents are known to accumulate metals in concentrations higher than those found in certain bivalves from polluted shallower environments such as industrialized estuaries (Childress \& Fisher, 1992). The Jaco Scar is located south of the mouth of the Gulf of Nicoya estuary. As a comparison of maximum concentrations $(\mu \mathrm{g} / \mathrm{g})$ of metals in non-depurted specimens of the intertidal razor clam, Tagelus affinis from a sand flat in the upper Gulf (Vargas et al., 2015) indicates that the razor clam accumulated certain metals more than the Jaco Scar clams, while other metals were within the range. However, T. affinis was able to lower concentrations of certain metals after a $72 \mathrm{~h}$ depuration in clean sea water (Vargas et al., 2015). Higher concentrations of $\mathrm{Fe}$ and $\mathrm{Zn}$ in tissues of $T$. affinis and other invertebrates from the sand flat were related to the presence of metal rich sediments at the site. Other metals were found in concentrations commonly found in non-industrialized estuaries (Vargas, Acuña-González, Vásquez, \& Sibaja-Cordero, 2016).

In a study of several mid Atlantic hydrothermal vent fields, Koshinsky, Kaush, \& Borowski (2014) reported concentrations of metals in the mussel Bathymodiolus spp. The maximum concentrations $(\mu \mathrm{g} / \mathrm{g})$ were: $\mathrm{Fe}(1$ 495), $\mathrm{Cu}$ (352), Zn (187), Pb (29.7), Mn (15.2), $\mathrm{Cd}$ (11.1). Higher concentrations of $\mathrm{Cu}, \mathrm{Zn}$, and $\mathrm{Pb}$ were found in the gills.

Concentrations of certain metals such as $\mathrm{Fe}, \mathrm{Cd}, \mathrm{Mn}$ and $\mathrm{Pb}$ from the Jaco Scar seep mussel were lower than those reported in mussels from the hydrothermal vent site, while $\mathrm{Cu}$ and $\mathrm{Zn}$ were within the range.

The Jaco Scar and Mounds 11 and 12 are promising ecosystems for future joint collaborative efforts involving multidisciplinary approaches.

\section{ACKNOWLEDGMENTS}

We thank K.M. Brown, for the collection of samples at the Jaco Scar during DSRV 
Alvin dive 4129. The metal analysis was made possible by grants from the Costa Rica-United States of America Foundation for Cooperation (CRUSA), and the University of Costa Rica (UCR). Projects 808-AO-506 and 808-A3526. We thank Jenaro Acuña-González, Eddy Gómez and Jairo Garcia for their help in the chemical laboratory. The hand drawing of the shells was prepared by Fiorella Jiménez.

\section{RESUMEN}

Metales en los bivalvos del emisor frío de Jaco Scar, Costa del Pacífico de Costa Rica. La investigación del mar profundo ha hecho descubrimientos significativos gracias a la disponibilidad de mapeo batimétrico de alta resolución y vehículos capaces de llegar a emisores hidrotermales y emisores fríos. El margen continental del Pacifico de Costa Rica incluye emisores de metano habitados por almejas vesicómidas en las que es esperable la acumulación de metales. Son escasos los datos sobre metales en almejas de emisores fríos. Por lo tanto, los objetivos de este estudio son el presentar datos de las concentraciones de $\mathrm{Al}, \mathrm{Cd}, \mathrm{Cu}$, $\mathrm{Fe}, \mathrm{Pb}, \mathrm{Mn}, \mathrm{Ni}, \mathrm{Sb}$ y $\mathrm{Zn}$ en muestras de siete almejas, un mejillón, sedimento y roca, junto con datos morfométricos. Los bivalvos (Archivesica sp.?) fueron recolectados en el 2005 a una profundidad de $1888 \mathrm{~m}$ en el Jacó Scar $\left(09^{\circ} 06^{\prime}\right.$ $\mathrm{N}-84^{\circ} 50^{\prime} \mathrm{W}$ ) durante la inmersión 4219 del DSRV Alvin. Los metales fueron analizados por Absorción Atómica de llama (FAAS) y Absorción Atómica en Horno de Grafito (GFAAS). Las concentraciones están en $\mu \mathrm{g} / \mathrm{g}$ peso seco. El orden decreciente de concentraciones máximas y su ámbito en tejidos de siete almejas, fueron: $\mathrm{Zn}(43.4-266.3)>\mathrm{Fe}$ $(27.2-100.0)>\mathrm{Al}(5.0-69.9)>\mathrm{Cd}(0.11-12.23)>\mathrm{Sn}(2.8$ - 9.5) > Cu (4.0 - 7.3) > Mn (1.1 - 2.2) > Pb (0.24 - 0.79) > $\mathrm{Ni}(0.19$ - 0.58). Las branquias tenían las máximas concentraciones de Fe y Al. Las concentraciones máximas en el único ejemplar de mejillón, fueron: Zn (80.4 - branquias), Fe (70.6 - branquias), Cu (31.0 - branquias), Al (26.6 branquias), Sn (4.87 - manto), Mn (1.7 - manto), Ni (0.97 - músculo), $\mathrm{Pb}$ (0.69 - músculo), Cd (0.57 - branquias). La muestra de sedimento contenía: Al (40 800), Fe (26500), Mn (72.0), Zn (64.7), Cu (29.4), Ni (19.3), Sn (15.5), $\mathrm{Pb}$ (2.98), Cd (0.16); mientras que el fragmento de roca contenía: Fe (15 650), Al (9 240), Mn (169.9), Sn (99.5), $\mathrm{Zn}$ (36.5), Ni (20.4), Cu (13.4), Pb (1.6), Cd (trazas). Las branquias de las almejas concentraron metales come el Fe y el Al. El Fe estuvo bajo el ámbito reportado para almejas de emisores hidrotermales, mientras que las concentraciones de otros metales estuvieron cerca del ámbito inferior. Las concentraciones de $\mathrm{Fe}, \mathrm{Cd}, \mathrm{Mn}, \mathrm{y} \mathrm{Pb}$ en tejidos del mejillón fueron menores que las de mejillones en emisores hidrotermales, mientras que las de $\mathrm{Cu}$ y $\mathrm{Zn}$ estuvieron dentro del ámbito. Metales en las muestras de sedimento y roca son muy ricas en ciertos metales como $\mathrm{Al}$ y Fe y muy pobres en otros, como el Cd. Existe una escasez de datos sobre metales y contaminantes en almejas y otras especies de la macrofauna en emisores fríos de Costa Rica. Los datos presentados deben ser complementados en estudios futuros sobre la geoquímica, biología y manejo de estos sistemas.

Palabras clave: emisores de metano, Vesicomyidae, Plioclardiinae, tectónica, subducción.

\section{REFERENCES}

Audzijonyte, A., Krylova, E. M., Sahling, H., \& Vrijenhoek, R. C. (2012). Molecular taxonomy reveals broad trans-oceanic distribution and high species diversity of deep-sea clams (Bivalvia: Vesicomyidae: Pliocardiinae) in chemosynthetic environments. Systematics and Biodiversity, 10(4), 403-415.

Calyptogena diagonalis, a new Vesicomyid bivalve from subduction zone cold seeps in the Eastern North Pacific. The Veliger, 42, 117-123.

Childress, J. J., \& Fisher, C. R. (1992). The biology of hydrothermal vent animals: Physiology, biochemistry, and authothrophic symbioses. Oceanography and Marine Biology, Annual Review, 30, 337-441.

Coan, E. V., \& Valentich-Scott, P. (2012) Bivalve seashells of Tropical West America: Marine bivalve mollusks from Baja California to Northern Peru. California, USA: Santa Barbara Museum of Natural History.

Cortés, J., \& Blum, S. (2008). Life to $450 \mathrm{~m}$ depth at Isla del Coco, Costa Rica. Revista de Biología Tropical, 56 (Suppl. 2), S189-S206.

Dalsgaard, T., Canfield, D. E., Peterson, J., Thamdrup, B., \& Acuña-González, J. (2003). $\mathrm{N}_{2}$ production by the anammox reaction in the anoxic water column of Golfo Dulce, Costa Rica. Nature, 422, 606-608.

Dean, H. K., Maurer, D., Vargas, J. A., \& Tinsman, C. H. (1986). Trace metal concentrations in sediment and invertebrates from the Gulf of Nicoya, Costa Rica. Marine Pollution Bulletin, 17, 128-131.

Demina, L. L. (2016). Trace metals in the water of the hydrothermal biotopes. The Handbook of Environmenal Chemistry, 50, 54-76.

Demina, L. L., Galkin, S. V., \& Shumulin, E. V. (2009). Bioaccumulation of some trace elements in the biota of hydrothermal field of the Guaymas Basin (Gulf of California). Boletín de la Sociedad Geológica Mexicana, 61, 31-45.

Dittmann, S., \& Vargas, J. A. (2001). Tropical tidal flat benthos compared between Australia and Central America. In K. Reise (Ed.), Ecological Comparisons of Sedimentary Shores. Ecological Studies, 151, 275-293.

Furi, E., Hilton, D. R., Tryon, M. D., Brown, K. M., McMurtry, G. M., Bruckmann, W., \& Wheat, C. G. 
(2010). Carbon release from submarine seeps a he Costa Rica fore arc: Implications for the volatile cycle at the Costa Rica convergent margin. Geochemistry, Geophysics, Geosystems, 11(4), Q04S21. doi: 10.1029/2009GC002810

Johnson, S. B., Krylova, E. M., Audzijonyte, A., Sahling, H., \& Vrijenhoek, R. C. (2017). Phylogeny and origins of vesicomyid clams. Systematics and Biodiversity, $15,346-360$.

Koshinsky, A., Kaush, M., \& Borowski, C. (2014). Metal concentrations in the tissues of the hydrothermal vent mussel Bathymodiolus: reflection of different metal sources. Marine Environmental Research, 95, 62-73.

Krylova, E. M., \& Sahling, H. (2006). Recent bivalve molluscs of the genus Calyptogena (Vesicomyidae). Journal of Molluscan Studies, 72, 359-395.

Krylova, E. M., \& Sahling, H. (2010). Vesicomyidae (Bivalvia): current taxonomy and distribution. PloS ONE, 5(4), e9957.

Levin, L. A. (2005). Ecology of cold seep sediments: Interactions of fauna with flow, chemistry and microbes. Oceanography and Marine Biology: An Annual Review, 43, 1-46.

Levin, L. A., Orphan, V. J., Rouse, G. W., Rathburn, A. G., Usler III, W., Cook, G. S., Strickrott, B. (2012). A hydrothermal seep on the Costa Rica margin: middle ground in a continuum of reducing ecosystems. Proceedings of the Royal Society B. doi:10.1098/ rspb.2012.0205

Levin, L., Mendoza, G. F., Grupe, B. M., González, J. P., Jellison, B., Rouse, G., Warren, A. (2015). Biodiversity on the rocks: Macrofauna inhabting authigenic carbonate at Costa Rica methane seeps. PloS ONE, 10(7), e0131080.

Martin, A. M., \& Gofredi, S. K. (2012). 'Pliocardia'krylovata, a new species of vesicomyid clam from cold seeps along the Costa Rica Margin. Journal of the Marine Biological Associaton of the United Kingdom, 95, 1127-1137.

Mau, S., Rehder, G., Sahling, H., Schleicher, T., \& Linke, P. (2012). Seepage of methane at Jaco Scar, a slide caused by seamount subduction offshore Costa Rica. International Journal of Earth Science. DOI 10.1007/ s00531-012-0822-z

Maurer, D. \& Vargas, J. A. (1984). Diversity of soft-bottom benthos in a tropical estuary: Gulf of Nicoya, Costa Rica. Marine Biology, 81, 97-106.

Maurer, D., Epifanio, C. E., Dean, H. K., Howe, S., Vargas, J. A., Dittel, A. I., \& Murillo, M. M. (1984). Benthic invertebrates of a tropical estuary: Gulf of Nicoya, Costa Rica. Journal of Natural History, 18, 47-61.

Opresko, D. M. \& Breedy, O. (2010). A new species of antipatharian coral (Cnidaria: Anthozoa: Antipatharia: Schizopathidae) from the Pacific coast of Costa Rica. Proceedings of the Biological Society of Washington, 123, 234-241.
Peek, A. S., Gaut, B. S., Feldman, R. A., Barry, J. P., Kochevar, R. E., Lutz, R. A., \& Vrijenhoek, R. C. (2000). Neutral and monneutral mitocondrial genetic variation in deep-sea clams from the Family Vesicomyidae. Journal of Molecular Evolution, 50, 141-153.

Roesijadi, G., \& Crecelius, E. A. (1984). Elemental composition of the hydrothermal vent clam Calyptogena magnifica from the East Pacific Rise. Marine Biology, 83, 155-161.

Ruelas-Inzunza, J., Soto, L. A., \& Páez-Osuna, F. (2003). Heavy metal accumulation in the hydrotherml vent clam Vesicomya gigas from Guaymas Basin, Gulf of California. Deep Sea Research I, 50, 757-761.

Starr, R. M., Cortés, J., Barnes, C. L., Green, K., \& Breedy. O. (2012). Characterization of deepwater invertebrates at Isla del Coco National Park and Las Gemelas Seamounts, Costa Rica. Revista de Biología Tropical, 60 (Suppl. 3), S303-S319.

Suess, E. (2014). Marine cold seeps and their manifestations: geological control, bio-geochemical criteria and environmental conditions. International Journal of Earth Science (Geol Rundsch), 103, 1889-1916.

Vargas, J. A. (1995). The Gulf of Nicoya estuary, Costa Rica: Past, present, and future cooperative research. Helgolander Meeresunthers, 49, 821-828.

Vargas, J. A. (1996). Ecological dynamics of a tropical intertidal mudflat community. In K. F. Nordstrom \& C. T. Roman (Eds.), Estuarine Shores: Evolution, Environments and Human Alterations (pp. 355-371). London: John Wiley \& Sons Ltd.

Vargas, J. A., Acuña-González, J., Gómez, E., \& Molina, J. (2015). Metals in coastal mollusks of Costa Rica. Revista de Biología Tropical, 63, 1007-1019.

Vargas, J. A., Acuña, J., Vásquez, F., \& Sibaja-Cordero, J. A. (2016). Brachiopods, sipunculans, enteropneusts and metals from two estuarine tidal flats, Pacific, Costa Rica. Revista de Biología Tropical, 64, 1311-1331.

Watanabe, H., Seo, E., Takahashi, Y., Yoshida, T., Kojima, S., Fujikura, K., \& Miyake, H. (2013). Spatial distribution of sister species of vesicomyid bivalves Calyptogena okutanii and Calyptogena soyoae along an environmental gradient in chemosynthetic biological communities in Japan. Journal of Oceanography, 69, 129-134.

Wehrtmann, I. S., Herrera-Correal, J., Vargas, R., \& Hernáez, P. (2010). Squat lobsters (Decapoda: Anomura: Galatheidae) from deepwater Pacific Costa Rica: species diversity, spatial and bathymetric distribution. Nauplius, 18, 69-77.

Wolff, M., Chavarría, J., Koch, V., \& Vargas, J. A. (1998). A trophic flow model of the Golfo de Nicoya, Costa Rica. Revista de Biología Tropical, 46 (Suppl. 6), S63-S79. 